\title{
Physicochemical and Bacteriological Water Quality Parameters in Relation to Land-use Practices at a Rural Catchment, Mbinga District, Tanzania
}

\author{
Harieth Hellar-Kihampa ${ }^{1, *}$ and Patrick Isdory Ndunguru ${ }^{2}$ \\ ${ }^{I}$ Faculty of Science, Technology and Environmental Studies, the Open University of Tanzania, \\ P. O. Box 23409, Dar es Salaam, Tanzania \\ ${ }^{2}$ Songea Urban Water Supply and Sanitation Authority, P. O. Box 363, Songea, Tanzania \\ *Corresponding author: e-mail: hariet.hellar@out.ac.tz; hhellar@yahoo.co.uk \\ ORCiD: https://orcid.org/0000-0002-6951-5243
}

Received 8 Jun 2021, Revised 16 Aug 2021, Accepted 18 Aug 2021, Published Aug 2021

DOI: https://dx.doi.org/10.4314/tjs.v47i3.35

\begin{abstract}
Data on physicochemical water quality parameters and contamination levels is crucial for protection and sustainable utilization of water resources. This study assessed the physicochemical water quality parameters, faecal coliform bacteria and nutrient loads in water at a catchment used for municipal supply in Mbinga District, Tanzania. Samples were seasonally collected from three areas characterized by distinct geographical features, settlement patterns and land-use practices, and analyzed using standard analytical protocols. Data were subjected to paired-sampled t-test and cluster analysis. The parameters varied as follows: $\mathrm{pH}(4.75-6.83)$; temperature $\left(16.4-26.2^{\circ} \mathrm{C}\right)$; electrical conductivity $(14.6-121.1 \mu \mathrm{S} / \mathrm{cm})$; total dissolved solids $(7.0-23.2 \mathrm{mg} / \mathrm{L})$; total suspended solids (BDL-35.5 mg/L); dissolved oxygen (8.6-23.8 mg/L); turbidity (0.1-68.1 NTU); faecal coliform (<1-76 FC/100 mL); nitrite (BDL-0.09 mg/L); nitrate and sulphate were not detected. Spatial variations were associated with land-use disparities. Comparison to risk-based regulatory thresholds for drinking water revealed the levels to be within the acceptable limits, with a few exceptions. Observed seasonal trends indicated an overall decrease in water quality during the wet season. Generally, results showed that water quality at the catchments satisfies requirements for domestic uses. However, the potential contamination risks from human activities call for regular monitoring.
\end{abstract}

Keywords: Physicochemical parameters; faecal contamination; water quality; surface water; Mbinga District.

\section{Introduction}

The quality of water from catchment areas used for domestic supply is an important issue of environmental and human health concern. Specifically, monitoring the spatial and temporal patterns of various water quality parameters in river catchments that are stressed by multiple factors are of paramount importance. Studies have shown that the quality of water in various catchment areas in Tanzania is declining due to contamination resulting from population pressures, human activities, climatic changes and geochemical processes. Researchers have characterized different aspects of water quality such as physicochemical parameters, dissolved inorganic ions, inorganic nutrients, toxic metals, persistent organic pollutants and pesticide residues in surface water resources in different areas across the country (e.g., HellarKihampa et al. 2013, Mihale 2015, Mataba et al. 2016, Shagega et al. 2020). 
In most rural areas of Tanzania, agriculture being the major economic activity makes farmers and grazers to often migrate to catchment areas looking for new areas and virgin lands for cultivation and grazing, situations which threaten the environmental qualities of the catchments (Kangalawe and Lyimo 2010). Rural communities in most parts of the country live near water sources for the purpose of getting their daily needs of domestic water close to their homes. The southern highlands of Tanzania is home to over 4 million inhabitants and encompasses five administrative Regions of Iringa, Njombe, Ruvuma, Mbeya and Rukwa (NBS 2013). It is one of the most fertile parts of the country, and also a touristic attraction area with features such as plateaus, grasslands, riverine forests, the Great Ruaha River and the Great Rift Valley. For the population of this area, the socio-economic activities are closely linked to their natural environment and their landscapes. Agriculture is the most important socialeconomic activity in the area, including Mbinga District, in Ruvuma Region, whereby more than $90 \%$ of the population depends on it to sustain their livelihood. Different types of food and cash crops are cultivated in the District (Nindi 2004). In some cases, the agricultural activities involve cutting down of natural vegetation, leaving the land bare and prone to soil erosion, cultivating crops close to the water sources that risks siltation and contamination by run-offs, and extensive use of fertilizers (MDC 2016).

Another widespread economic activity in Mbinga District is livestock keeping, though done in small scale level for income generation and family consumption purposes, where communities keep herds of cattle, goats, sheep and donkeys. In some locations of the District where there is grazing and hunting activities, there exists a practice of burning old grasses to allow new grasses to grow for the purpose of feeding animals and clearing the land for the next farming season. This practice often leads to forest fires and contamination risks to the water sources. The inappropriate land-use practices pose threats to the quality of surface waters at the catchment areas (Kangalawe and Lyimo 2010). Despite the potential threats, there are no documented studies that investigated surface water quality in Mbinga District.

This study therefore focused on assessing the water quality in a rural catchment in Mbinga District, Ruvuma Region, in the southern highlands of Tanzania. The aim was to determine levels of selected physicochemical and bacteriological water quality parameters as a basic step in investigating the impacts of anthropogenic activities and assessing the suitability of the water for human consumption. Due to the easy of their determination and interpretation, the physicochemical water quality parameters present a suitable means for initial indication of the water characteristics. The faecal coliform bacteria are regarded as indicators for the determination of the microbiological quality of water (e.g., Ferrer et al. 2020). In addition, determination of levels of inorganic nutrients, which have received increased attention in water quality monitoring, is important in this area. The selected water quality parameters in this study are significant since they can quickly determine the suitability of water for domestic uses, but also other properties of water. Apart from possible health effects, changes in these parameters may have other undesirable effects such as unsuitable odours and tests, damage to water equipment and reduced effectiveness of treatments for other contaminants (EWURA 2020). Concentrations are compared to guidelines for such variables in drinking water set by the WHO (2011), the Tanzanian requirements for natural potable water by the Tanzania Bureau of Standards (TBS 2008) as well as some other regional authorities such as EU (2017) and US EPA (1994).

\section{Materials and Methods \\ Description of the study area}

Mbinga District is located in Ruvuma Region in the Southern highlands part of Tanzania. It is located between $10^{\circ} 49^{\prime} 60^{\prime \prime} \mathrm{S}$ 
and $34^{\circ} 59^{\prime} 43^{\prime \prime} \mathrm{E}$ and the Universal Transverse Mercator (UTM) easting of 716,792.55 and northing of $8,789,635.10$, at an elevation of $1,250 \mathrm{~m}$ above sea level. The District covers an area of $11,396 \mathrm{~km}^{2}$, which is about $18 \%$ of the total land area of Ruvuma Region (MDC 2016). Generally, the Southern highlands of Tanzania like the rest of the country, has tropical climate influenced by various factors such as altitude and location, with distinct rainy and dry seasons. The dry season is usually longer, starting from June to October. There is a period of short rains which occurs in November to December and sometimes up to January. The long rains are between March and May, and these are the wettest months of the year, where it tends to rain continuously and heavily (Rowhani et al. 2011). Mbinga District had a population of 353,683 and an average annual population growth rate of $2.9 \%$ in 2012 (NBS 2013) and the District is estimated to have a population of about 440,500 as of 2021 .

The study area was grouped into three parts based on their distinct geographical features, population characteristics and social-economic activities. This was done for comparison purposes in assessing the impacts of land-use practices, and spatial variability of the measured parameters. The three groups of locations were the 'highland area (HA)'; the 'lowland area (LA)' and the 'new area (NA)'. The highland area is a mountainous zone encompassing the Livingstone and Matengo highlands. The area is characterized by farming activities, which have left the mountains and hills virtually naked, particularly in the old villages. Large farms of cash and food crops can be found on sides of the hills, extending up to the water sources. The lowland area lies at low elevation and the most downstream part of the rivers. It is almost a flat land with lower population density compared to the highland area. Rivers in this area carry large volumes of water, increasing as they flow from the highland area. The new area is inhabited by people who migrated from the highland area for the purposes of finding new areas for settlements, farming as well as grazing. The land in the locality is almost virgin, thus application of agrochemicals is limited, while cutting of trees for preparation of new farms is extensive.

\section{Sample collection}

Water samples were collected from thirteen (13) locations in rivers and streams within the three groups of locations. The criteria for selecting the water sources for sampling was based on those involved in the water schemes serving the population in the study area as monitored by the Songea Urban Water Supply and Sanitation Authority (SUWASSA). Seven (7) of the sites were located in the HA, three (3) in the LA and three (3) in the NA. Table 1 summarizes information on the sampling sites and their respective water sources. Two sampling campaigns were conducted for this study, aiming at the two extreme seasons in the area. The wet season samples were collected in March 2018, whereas the dry season samples were collected towards the end of June 2018. Sample were collected in clean prior labelled Teflon capped polyethylene bottles (1 litre), from exactly the same spots during each of the two seasons, as identified by a hand-held global positioning system (GPS). To collect the samples, the bottles were submerged with the mouth against the water current and filled in with water. Two aliquots of samples were taken in each case, the first were used for measurement of the field parameters on site and then discarded, and the second were placed into ice-cases at $<10^{\circ} \mathrm{C}$ and transported to the Ruvuma Regional Water Laboratory, where they were analyzed within 24 hours after sampling, there was no sample preservation.

\section{Sample analysis}

Water samples were analyzed for a total of eleven parameters; six of them $(\mathrm{pH}$, temperature, EC, TDS, DO, turbidity) were measured in-situ by hand-held portable waterquality instruments, whereas the remaining five (TSS, $\mathrm{NO}_{2}{ }^{-}-\mathrm{N}, \mathrm{NO}_{3}{ }^{-}-\mathrm{N}, \mathrm{SO}_{4}{ }^{2-}$ and $\mathrm{FC}$ ) were analyzed in the laboratory using standard analytical protocols. 
Tanz. J. Sci. Vol. 47(3) 2021

Table 1: Sampling sites

\begin{tabular}{|c|c|c|c|}
\hline Area & Sample code & Water source & Coordinates \\
\hline \multirow{7}{*}{$\begin{array}{l}\text { Highland } \\
\text { Area }\end{array}$} & HA1 & Nyoni & $\begin{array}{r}36 \mathrm{~L} 0750139 \mathrm{~N} \\
8803800 \mathrm{E}\end{array}$ \\
\hline & HA2 & Lupembe & $\begin{array}{rr}36 \mathrm{~L} & 0750139 \mathrm{~N} \\
& 8703800 \mathrm{E}\end{array}$ \\
\hline & HA3 & Ndengu & $\begin{array}{r}36 \mathrm{~L} \quad 0750139 \mathrm{~N} \\
8703800 \mathrm{E}\end{array}$ \\
\hline & HA4 & Myangayanga & $\begin{array}{r}36 \mathrm{~L} 0718172 \mathrm{~N} \\
8789485 \mathrm{E}\end{array}$ \\
\hline & HA5 & Mkumbi & $\begin{array}{r}36 \mathrm{~L} 0706267 \mathrm{~N} \\
8794853 \mathrm{E}\end{array}$ \\
\hline & HA6 & Ruhuwiko-Ndengu & $\begin{array}{r}36 \mathrm{~L} \\
0703845 \mathrm{~N} \\
8809995 \mathrm{E}\end{array}$ \\
\hline & HA7 & Maji Yard & $\begin{array}{r}36 \mathrm{~L} 0727682 \mathrm{~N} \\
8805891 \mathrm{E}\end{array}$ \\
\hline \multirow{3}{*}{$\begin{array}{l}\text { Lowland } \\
\text { Area }\end{array}$} & LA1 & Kigonsera & $\begin{array}{r}36 \mathrm{~L} \\
0720742 \mathrm{~N} \\
8800797 \mathrm{E}\end{array}$ \\
\hline & LA2 & Matiri & $\begin{array}{r}36 \mathrm{~L} 0719711 \mathrm{~N} \\
8790038 \mathrm{E}\end{array}$ \\
\hline & LA3 & Lipumba & $\begin{array}{r}36 \mathrm{~L} 0724276 \mathrm{~N} \\
8799836 \mathrm{E}\end{array}$ \\
\hline \multirow{3}{*}{$\begin{array}{l}\text { New } \\
\text { Area }\end{array}$} & NA1 & Mahande & $\begin{array}{r}36 \mathrm{~L} 0731111 \mathrm{~N} \\
8791702 \mathrm{E}\end{array}$ \\
\hline & NA2 & Ruhuwiko-Utiri & $\begin{array}{r}36 \mathrm{~L} \\
0719713 \mathrm{~N} \\
8789491 \mathrm{E}\end{array}$ \\
\hline & NA3 & Kitanda & $\begin{array}{r}36 \mathrm{~L} 0717744 \mathrm{~N} \\
8789719 \mathrm{E}\end{array}$ \\
\hline
\end{tabular}

Measurements for $\mathrm{pH}$ and water temperature were done by a digital $\mathrm{pH}$ meter (Platinum Series Model 51910-88 Hach Co., USA) that measure the two parameters at the same time. The $\mathrm{pH}$ meter was calibrated using the manufacture-provided buffer solutions of $\mathrm{pH} 4.0$ and 7.0 before the measurements on each day and re-calibrated after every ten measurements. Electrical conductivity and TDS were measured simultaneously using a digital EC/TDS meter (Model 51975-00, Hach Co. USA), which was calibrated using the manufacturer-supplied standard $\mathrm{NaCl}$ solutions of known conductivity, checked against four scale ranges of the meter. Dissolved oxygen was measured by using a digital DO meter (Model 51970-88, Hach Co., USA), which was calibrated using the Water-saturated Air calibration method as described in the manufacturer's manual. Turbidity was measured using an electronic turbidity meter (nephelometer) (Model HI98713, HANNA Instruments Inc., Rhode Island, USA) that utilizes the principle of light scatter to measure turbidity in terms of nephelometric turbidity units (NTU). Measurements involved calibration of the meter with manufacturer's supplied turbidity standards at the beginning of each sampling campaign.

The measurement of TSS in water samples was carried out by the filtration process (APHA/AWWA/WEF, 2005). In this method, $250 \mathrm{ml}$ water sample was poured on preweighed Whatman ${ }^{\circledR}$ glass microfiber filters (2.0 $\mu \mathrm{m}$ particle retention) and filtered. After completion of the filtration process, the filter 
was removed and placed in an aluminium dish and heated in an oven at $100{ }^{\circ} \mathrm{C}$ for $2-3$ hours to completely dry off the remaining water. The filter was then re-weighed to measure the gain in filter weight, which corresponded to the TSS content, expressed in mass per volume of sample filtered $(\mathrm{mg} / \mathrm{L})$. The method is well approved and used by different researchers in similar studies (e.g., Rahmanian et al. 2015).

The nutrients were analyzed by standard colorimetric methods (APHA/AWWA/WEF, 2005). Nitrite-nitrogen $\left(\mathrm{NO}_{2}{ }^{-}-\mathrm{N}\right)$ was determined by method $4500-\mathrm{NO}_{2}{ }^{-} \mathrm{B}$, which is based on the formation of a reddish-purple azo dye produced at a $\mathrm{pH}$ of $2.0-2.5$ by coupling diazotized sulphanilic acid with $\mathrm{N}-(1-$ naphthyl)-ethylenediamine dehydrochloride. The colour absorbance was measured by a spectrophotometer at $543 \mathrm{~nm}$. Sample concentration was computed through the use of standard curves. The method is applicable to concentration ranging from $0.01 \mathrm{mg} / \mathrm{L}$.

Nitrate-nitrogen $\left(\mathrm{NO}_{3}{ }^{-}-\mathrm{N}\right)$ was determined by the cadmium $(\mathrm{Cd})$ reduction method 4500 $\mathrm{NO}_{3}{ }^{-} \mathrm{E}$ (APHA/AWWA/WEF 2005). Water samples $(50 \mathrm{~mL})$ were first filtered through $0.45 \mu \mathrm{m}$-pore diameter membrane to remove turbidity. The $\mathrm{NO}_{3}^{-}-\mathrm{N}$ ion was then reduced quantitatively to nitrite $\left(\mathrm{NO}_{2}{ }^{-}-\mathrm{N}\right)$ using commercially available $\mathrm{Cd}$ granules treated with copper sulphate $\left(\mathrm{CuSO}_{4}\right)$ to form a $\mathrm{Cu}$ coating. The $\mathrm{NO}_{2}{ }^{-} \mathrm{N}$ produced was then determined by diazotizing with sulphanilamide and coupling with $\mathrm{N}$-(1 naphythyl)ethylenediamine to form a highly coloured azo dye that was measured colorimetrically. The detection limit for this method is $0.01 \mathrm{mg} / \mathrm{L}$.

Sulfate was determined as $\mathrm{SO}_{4}{ }^{2-}$ ion using the turbidimetric method $4500-\mathrm{SO}_{4}{ }^{2-} \mathrm{E}$ (APHA/AWWA/WEF 2005). The method is based on the principle of conversion of the $\mathrm{SO}_{4}{ }^{2-}$ ion to barium sulfate $\left(\mathrm{BaSO}_{4}\right)$ under controlled conditions. In the procedure, 100 $\mathrm{mL}$ of water sample was added with buffer solution, prepared as per the description in the method, and about $50 \mathrm{~g}$ of $\mathrm{BaCl}_{2}$ crystals. The resulting solution was then stirred for one minute and thereafter its absorbance determined by a spectrophotometer at $420 \mathrm{~nm}$. The $\mathrm{SO}_{4}{ }^{2-}$ concentration was measured by comparison with standard curves. The method is applicable to $\mathrm{SO}_{4}{ }^{2-}$ concentration from of 1 mg/L (APHA/AWWA/WEF 2005).

The bacteriological test was conducted using the membrane filter technique, Standard Method 9222 D (APHA/AWWA/WEF 2005). In the procedure, $100 \mathrm{~mL}$ of water sample was filtered through a membrane filter $(0.45 \mu \mathrm{m}$ pore diameter) and placed on membrane faecal coliform agar (mFC agar) containing aniline blue as an indicator, then incubated at $44.5^{\circ} \mathrm{C}$ for 24 hours in a water-bath. The resulting colonies that are various shades of blue are positive for faecal coliforms, were then observed through a binocular under fluorescent light and counted. The concentration is given as number of colony-forming units (CFU) per $100 \mathrm{~mL}$ of water.

\section{Quality assurance and control}

The quality of the analytical data was assured in all steps of the study, i.e., sample collection, laboratory analysis, and data checks. In the sampling procedure, all tools were thoroughly cleaned and rinsed with distilled water. Samples were carefully handled by ensuring correct labelling of the sample bottles, packaging and transporting to the laboratory. Field data were carefully recorded in triplicate at each point. In the laboratory, the quality of nutrient analysis was assured by analyzing samples of distilled water as blank samples, then after ensuring that the blank samples were free of the target analytes, they were spiked with standard solutions of the analytes prepared by diluting a stock solution at their method detection limits and then processed by the same method as described for samples, with the objective of ensuring that the spiked concentrations are recovered.

The quality of bacteriological test was assured by the use sterilized membranes and ensuring maintenance of the prescribed temperature throughout the incubation period. Furthermore, procedural errors and the presence of contamination were tested through 
the negative and positive plates test as described by Myers and Sylvester (1997). The data checks were done by ensuring that the obtained results were within the expected ranges of a particular parameter, that they were physically and scientifically possible, and that they were within the detection limits of the method used.

\section{Data analysis}

Descriptive statistics was used to summarize results for concentration ranges, means and standard deviations. The datasets were tested for normality using the Shapiro-Wilk test, in which a null hypothesis that a variable is normally distributed was rejected if $\mathrm{p}<0.05$. The Wilcoxon Signed Ranks test for paired samples was used to determine statistically significant difference in the measured values between the two seasons. Considered significant different were those with $\mathrm{p}<0.05$. The dataset was also subjected to Spearman Rank correlation analysis for non-normal data to evaluate the relationships among the measured parameters. Hierarchical Cluster Analysis (HCA) was performed with the objective of studying the patterns of similarities and differences among the 13 sited. All statistical analyses were carried out using the statistical packages IBM SPSS Statistics 23.0.

\section{Results and Discussion \\ Levels of the measured parameters in the water samples}

The descriptive statistical data of the measured parameters in the thirteen stations during the two seasons are summarized in Table 2. The normality test showed that all parameters were not normally distributed, due to the presence of extreme values.

Table 2: Descriptive statistics of the physicochemical parameters measured in the 13 stations during the two seasons

\begin{tabular}{|c|c|c|c|c|}
\hline \multirow[t]{2}{*}{ Parameter } & \multicolumn{2}{|c|}{ Dry season $(n=13)$} & \multicolumn{2}{|c|}{ Wet season $(n=13)$} \\
\hline & Range & Mean \pm SD & Range & Mean \pm SD \\
\hline $\mathrm{pH}$ & $4.75-6.83$ & $5.75 \pm 0.71$ & $4.70-6.40$ & $5.38 \pm 0.57$ \\
\hline Temperature $\left({ }^{\circ} \mathrm{C}\right)$ & $16.4-26.2$ & $20.7 \pm 2.3$ & $19.2-24.5$ & $22.7 \pm 1.8$ \\
\hline $\mathrm{EC}(\mu \mathrm{S} / \mathrm{cm})$ at $25^{\circ} \mathrm{C}$ & $15.8-121.1$ & $46.8 \pm 31.5$ & $14.6-108.5$ & $15.4 \pm 29.2$ \\
\hline TDS (mg/L) & $8.0-59.0$ & $23.2 \pm 15.5$ & $7.0-53.0$ & $21.7 \pm 13.6$ \\
\hline TSS (mg/L) & BDL-30.0 & $8.2 \pm 11.4$ & BDL-35.0 & $9.1 \pm 11.5$ \\
\hline $\mathrm{DO}(\mathrm{mg} / \mathrm{L})$ & $13.6-23.8$ & $18.6 \pm 3.2$ & $8.6-19.4$ & $15.9 \pm 4.6$ \\
\hline Turbidity (NTU) & $0.6-33.5$ & $6.33 \pm 9.07$ & $0.1-68.1$ & $7.50 \pm 14.1$ \\
\hline $\begin{array}{ll}\text { Faecal } & \text { Coliform } \\
(\mathrm{FC} / 100 \mathrm{~mL}) & \end{array}$ & $<1-36$ & $6.30 \pm 9.07$ & $<1-76$ & $14.65 \pm 21.42$ \\
\hline $\mathrm{NO}_{2}{ }^{-}-\mathrm{N}(\mathrm{mg} / \mathrm{L})$ & BDL-0.09 & $0.002 \pm 0.005$ & BDL-0.07 & $0.005 \pm 0.007$ \\
\hline $\mathrm{NO}_{3}^{-}-\mathrm{N}(\mathrm{mg} / \mathrm{L})$ & BDL & - & BDL & - \\
\hline $\mathrm{SO}_{4}^{2-}(\mathrm{mg} / \mathrm{L})$ & $\mathrm{BDL}$ & - & BDL & - \\
\hline
\end{tabular}

$\mathrm{BDL}=$ Below Detection Limit.

Figure 1 represents bar graphs depicting the respective concentrations of the measured parameters in each sampling site. Table 3 summarizes the drinking-water quality maximum allowable limits of the measured parameters as given by the WHO (2011), EU (2017), US EPA (1994) and the TBS (2008)
(TZS 789: 2008), for comparison purposes. The results of Spearman rank correlation analysis used to evaluate associations between pairs of the measured parameters in the 13 investigated stations are summarized in Table 4. 


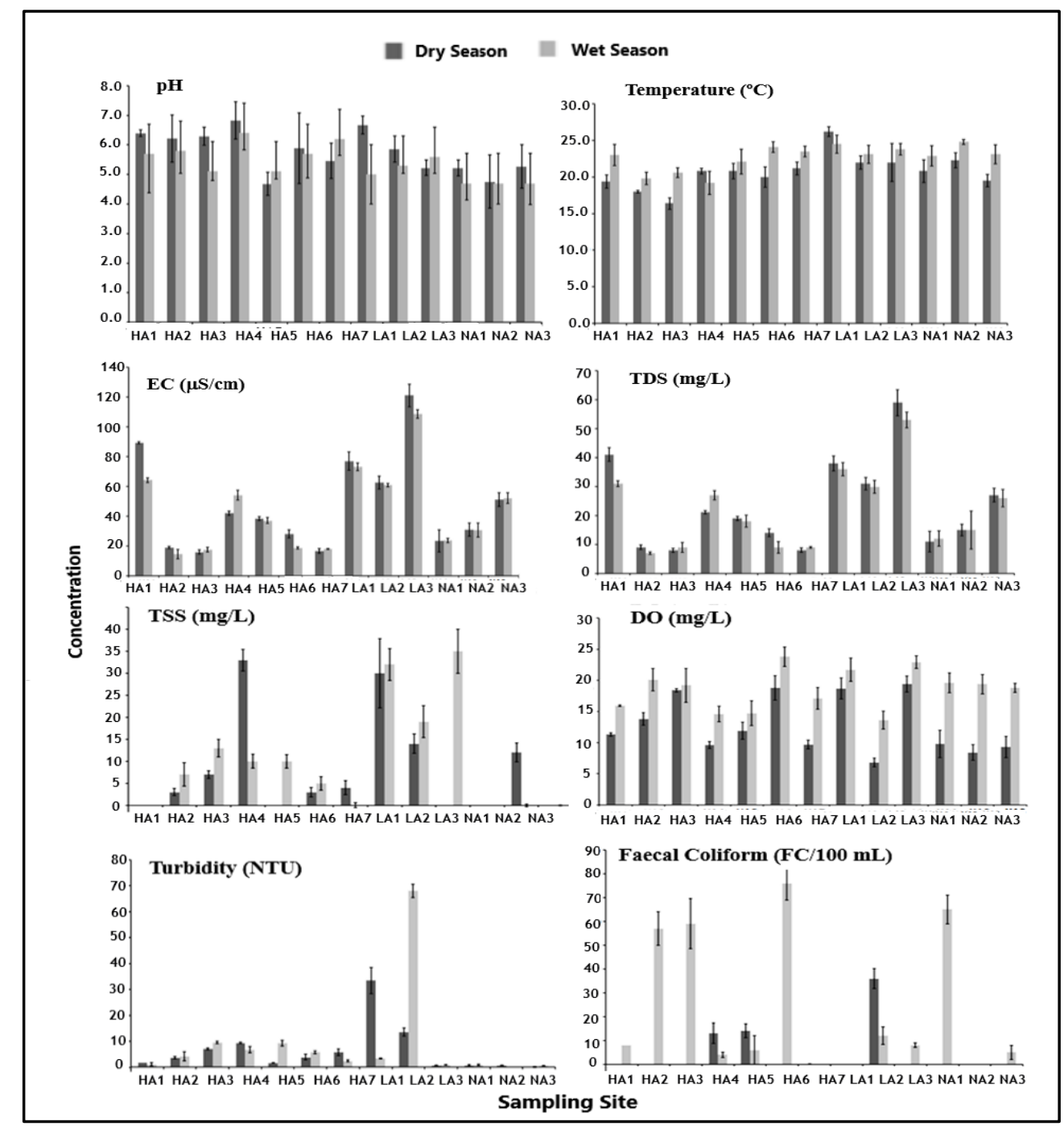

Figure 1: Concentration ranges of the measured parameters in the 13 sampling sites during the two seasons.

The data in Table 2 show that the $\mathrm{pH}$ values were slightly acidic to near neutral during both seasons, ranging between 4.75 and 6.83 during the dry season, and from 4.70 to 6.40 during the wet season. Typical values for natural river and stream water are said to range between 6.0 and 8.5 (Baird and Bridgewater 2017). Table 3 shows that the permissible limit for potable water by WHO ranges from 6.5 to 9.2 (WHO 2011), whereas the Tanzanian standard is $6.5-$
8.5 (TBS 2008). The pH values were lower than the two standards at NA1, NA2 and NA3, during the wet season, as it can be viewed in Figure 1. The three sampling locations are within an area with limited human activities and pollution sources (newland area); hence the acidic characteristics of water at this location might be due to natural causes. There are various natural factors that can lead to low $\mathrm{pH}$, including geology of the watershed (Araoye 
2009). The low values recorded at these locations however is not a good sign, since studies have shown that low $\mathrm{pH}$ levels may favour the solubility of heavy metals because when the level of hydrogen ions increases, metal cations such as aluminium, lead, copper and cadmium are released into the water instead of being absorbed into the sediment (Patil et al. 2012). The $\mathrm{pH}$ values were also positively correlated with turbidity levels (Table 4).

Table 3: Comparison of concentration ranges measured in this study to allowable limits for drinking water quality of some agents

\begin{tabular}{lccccc}
\hline Parameter & This study & WHO & EU & US EPA & Tanzania \\
\hline $\mathrm{pH}$ & $4.70-6.83$ & $6.5-9.2$ & $6.5-8.5$ & $6.5-8.5$ & $6.5-8.5$ \\
Temperature $\left({ }^{\circ} \mathrm{C}\right)$ & $16.4-22.7$ & & & & $20-35$ \\
$\mathrm{EC}(\mu \mathrm{S} / \mathrm{cm})$ at $25{ }^{\circ} \mathrm{C}$ & $14.6-121.1$ & 2500 & 2500 & 1000 & - \\
$\mathrm{TDS}(\mathrm{mg} / \mathrm{L})$ & $7.0-59.0$ & 1000 & - & 500 & 1000 \\
$\mathrm{TSS}(\mathrm{mg} / \mathrm{L})$ & BDL-35.0 & No guideline & Not mentioned & - & No guideline \\
$\mathrm{DO}(\mathrm{mg} / \mathrm{L}) 25^{\circ} \mathrm{C}$ & $8.6-23.8$ & No guideline & Not mentioned & - & - \\
Turbidity $(\mathrm{NTU})$ & $0.1-68.1$ & $<5$ & 3 & - & 5 \\
Faecal coliforms & $<1-76$ & No guideline & - & 0 & $<3$ \\
$(\mathrm{FC} / 100 \mathrm{~mL})$ & $0.07-0.08$ & 3 & - & 0.5 & - \\
$\mathrm{NO}_{2}^{-}-\mathrm{N}(\mathrm{mg} / \mathrm{L})$ & $\mathrm{BDL}$ & 45 & - & 50 & 75 \\
$\mathrm{NO}_{3}^{-}-\mathrm{N}(\mathrm{mg} / \mathrm{L})$ & $\mathrm{BDL}$ & & & & \\
$\mathrm{SO}_{4}{ }^{2-}(\mathrm{mg} / \mathrm{L})$ & & & & & \\
\hline
\end{tabular}

Table 4: Spearman correlation matrix between pairs of water quality parameters $(n=26)$

\begin{tabular}{llllllllll}
\hline & $\mathrm{pH}$ & Temp & $\mathrm{EC}$ & TDS & TSS & DO & Turbidity & $\mathrm{FC}$ & $\mathrm{NO}_{2}{ }^{-}$ \\
\hline $\mathrm{pH}$ & 1.000 & & & & & & & & \\
Temp & -0.342 & 1.000 & & & & & & & \\
EC & 0.033 & 0.312 & 1.000 & & & & & & \\
TDS & -0.008 & 0.345 & $0.952^{* *}$ & 1.000 & & & & & \\
TSS & 0.300 & 0.159 & 0.160 & 0.102 & 1.000 & & & & \\
DO & 0.198 & -0.185 & 0.045 & 0.064 & 0.083 & 1.000 & & \\
Turbidity & $0.524^{* *}$ & -0.108 & -0.141 & -0.225 & $0.661^{* *}$ & -0.111 & 1.000 & & \\
FC & -0.145 & 0.097 & -0.103 & -0.105 & 0.231 & $-0.513^{* *}$ & 0.325 & 1.000 & \\
Nitrite & -0.365 & 0.204 & -0.099 & -0.021 & 0.280 & -0.318 & 0.146 & 0.215 & 1.000 \\
\hline
\end{tabular}

**Correlation is significant at the 0.01 level (2-tailed).

The water temperature ranged between 16.4-26.2 ${ }^{\circ} \mathrm{C}$ and $19.2-24.5^{\circ} \mathrm{C}$ during the dry and the wet seasons, respectively (Table 2). These ranges reflect the climatic conditions of the area and varied according to altitude and season (Figure 1). The HA sites being located at the highest elevation and hence the coolest part of the catchment had the lowest water temperatures, while the highest temperatures were recorded at the LA sites which are in flat land.

The overall range for EC recorded in this study $\left(14.6-121.1 \mu \mathrm{S} / \mathrm{cm}\right.$ at $\left.25^{\circ} \mathrm{C}\right)$ was within the normal values for natural water which, is expected to vary between 50 and $1500 \mu \mathrm{S} / \mathrm{cm}$ (Baird and Bridgewater 2017). It was also below the maximum limits set by the WHO, EU and EPA (Table 3), which shows that the water is in good quality with respect to anthropogenic inputs of dissolved solutes. Figure 1 shows that the highest EC values were recorded at LA3 during both seasons. Furthermore, the other two LA sites, i.e., LA1 and LA2 also had relatively high concentrations of EC compared to the rest of the sites, except HA1. However, this does not 
raise much alarm since the levels are well below prescribed limits.

Total dissolved solids (TDS) are the inorganic matters and small amounts of organic matter, which are present as solution in water (Rahmanian et al. 2015). The data in Table 2 show that the TDS levels in this study ranged from 8.0 to $59.0 \mathrm{mg} / \mathrm{L}$ during the dry season and 7.0-53.0 $\mathrm{mg} / \mathrm{L}$ during the wet season. These concentrations are well below the acceptable standards for drinking water quality set by TBS, the WHO and the US EPA, as shown in Table 3. The highest levels during both seasons were measured at sampling site LA3, followed by LA1 and LA2 (Figure 1). Levels of TDS may be used as an indication of decomposition and mineralization of organic matter from various human activities in an area (Siosemarde et al. 2010). The relative high level of TDS at the three LA locations, which are located at the lowest part of the study area, with most human activities compared to the other studied locations, indicates possibility of inputs from anthropogenic sources. Concentrations of TDS and EC are normally highly correlated because the conduction of electric current in an electrolyte solution primarily depends on the concentration of the dissolved ionic species (Siosemarde et al. 2010). The TDS values measured in this study were almost half of the EC values of the respective sites, and followed the same trend, as it can be visualized in Figure 1 and the two parameters were strongly correlated $(r=0.952)$ as shown in Table 4.

Total suspended solids (TSS) are particles of organic or inorganic nature that are larger than 2 microns found in the water column, anything smaller than that is considered a dissolved solid (Baird and Bridgewater 2017). The significance of TSS in water quality assessments is the possibility of potentially harmful substances such as heavy metals, organic contaminants and organic matter to be adsorbed onto TSS and affect the quality of water (Rossi et al. 2006). The data in Table 2 indicate that the overall TSS concentration range found in this study was from below the detection limit to $35.0 \mathrm{mg} / \mathrm{L}$. The TBS has not set specific limit for TSS in potable water as shown in Table 3. The highest level of TSS was measured at site LA3 during the wet season; this seems to probably be from a point source since the same site had levels below detection limit during the dry season. Practices such as agricultural tillage and removal of vegetation during farm preparations, which are common in the area, may have triggered this sudden TSS increase at the site. Relatively high levels were also measured at HA4 and LA1, the latter had high concentrations during both seasons (Figure 1). Most of the other HA and NA sites that are considered less impacted by human activities had low levels of TSS.

Concentrations of DO were found to range between 13.6 and $23.8 \mathrm{mg} / \mathrm{L}$ during the dry season and 8.6 and $19.4 \mathrm{mg} / \mathrm{L}$ at $25^{\circ} \mathrm{C}$ during the wet season. No guideline has been provided for DO in drinking water, however the concentrations of DO in unpolluted water are normally about $8.0-10 \mathrm{mg} / \mathrm{L}$ at $25^{\circ} \mathrm{C}$ (Baird and Bridgewater 2017). Some authors recommend a minimum level of $2.4 \mathrm{mg} / \mathrm{L}, 30 \%$ at $25^{\circ} \mathrm{C}$ for the protection of aquatic life (Baird and Bridgewater 2017). Water is considered generally healthy when its DO range is 6.5-8.0 $\mathrm{mg} / \mathrm{L}$ and 80-120\% (Araoye 2009). The DO values measured in all the 13 sites during both seasons can therefore be considered to be healthy, and indicate that the water is of good quality.

Turbidity is a measure of the relative clarity of water that indicates the levels of suspended and colloidal matter, such as clay, silt, finely divided organic and inorganic matter and microscopic organisms that may interfere with the passage of light through the water (Awoyemi et al. 2014). Turbidity values measured in this study ranged from 0.1 to 68.1 NTU whereas the limit set by TBS and the WHO are below 5 NTU. The obtained results show that turbidity values were mostly within the permissible limits in eight stations and exceeded the permissible limits in five stations, i.e., LA2, HA3, HA4, HA5 and HA6. The highest value of turbidity (68.1 NTU) was 
measured at LA2 during the wet season, followed by LA1 which had 33.5 NTU. Turbidity is commonly used as an indicator for the general condition of the drinking water and is closely related to total suspended solids (TSS). The two parameters measure approximately the same water quality property; however, TSS provides an actual weight of the particulate material present in the sample (Araoye 2009). In this study, the TSS and turbidity were also strongly positively correlated $(r=0.661)$.

Faecal coliforms were detected in water samples from 10 out of the 13 sampling sites that were investigated in this study in varied concentrations of up to $36 \mathrm{FC} / 100 \mathrm{~mL}$ during the dry season and up to $76 \mathrm{FC} / 100 \mathrm{~mL}$ during the wet season (Table 2). The highest concentration was measured at HA6 during the wet season, whereas it was not detected during the dry season at this particular site, this indicates that water at the location was probably contaminated during rainfalls. Sites HA2 and HA3 also recorded relatively high concentrations of FC. The Tanzanian standard limit of FC in drinking water is less than $3 \mathrm{FC}$ in $100 \mathrm{~mL}$ of water, which was significantly exceeded in some of the locations (Figure 1). Faecal coliform bacteria are used as indicators of possible sewage contamination because they are commonly found in human and animal faeces. Although generally not harmful themselves, they indicate possible presence of disease-causing micro-organisms that also live in human and animal digestive systems. Their presence in concentrations above allowable limits in water used for domestic purposes is a potential health risk. One possible source of FC at the sites is application of manure in farms, e.g., Tyrrel and Quinton (2003) found evidence to suggest that faecal contamination of watercourses occur from diffuse sources from agricultural lands receiving animal faecal wastes. Similarly, results from a study by Mishra et al. (2008) observed that manure application yielded significant bacterial loading to downstream water bodies, especially when rainfall occurred soon after the application.
This might also be the case in this study because the results show that in all the sites where FC was detected, it was mostly during the wet season.

Nutrients are particularly important in surface water, where they are the main contributors to eutrophication. The nutrients measured in this study are nitrate-nitrogen $\left(\mathrm{NO}_{3}{ }^{-}-\mathrm{N}\right)$ and nitrite-nitrogen $\left(\mathrm{NO}_{2}{ }^{-} \mathrm{N}\right)$. Nitrite $\left(\mathrm{NO}_{2}{ }^{-}\right)$is not usually present in significant concentrations except in a reducing environment, because nitrate $\left(\mathrm{NO}_{3}{ }^{-}\right)$is the more stable oxidation state (Manuel 2014). The data obtained in this study (Table 2) indicate low concentrations of $\mathrm{NO}_{2}^{-}$ranging from below detection limit to $0.09 \mathrm{mg} / \mathrm{L}$, whereas $\mathrm{NO}_{3}{ }^{-}$levels were below detection limit in all sites. It has been suggested that in the presence of nitrogen-fixing bacteria, nitrate may be degraded to nitrite (Rohrer 2013), thereby causing concentrations of $\mathrm{NO}_{2}^{-}$to be higher than that of $\mathrm{NO}_{3}{ }^{-}$.

The highest levels of $\mathrm{NO}_{2}^{-}-\mathrm{N}$ during both seasons were measured at site LA2. This site is characterized by large herds of cattle as earlier described and may be prone to nutrient contamination. Both of the two nitrogen compounds may reach surface water through agricultural activities, including applications of inorganic nitrogenous fertilizers and manures, which is also common in the area (MDC 2016). The WHO maximum limit for $\mathrm{NO}_{3}{ }^{-}$is 45 $\mathrm{mg} / \mathrm{L}$, whereas that of $\mathrm{NO}_{2}^{-}$is $3 \mathrm{mg} / \mathrm{L}$ (Table 3). Sulphate ion was not detected within the limits of the employed method in any of the sampling sites. The levels detected in this study are well below the limit set by WHO for drinking water standard. This is a good sign and an indication that water at the study site is not contaminated by these compounds.

\section{Seasonal variations}

For the $\mathrm{pH}$ measurements, a significant seasonal difference was observed where samples collected during the dry seasons had higher values $(\mathrm{n}=13, \mathrm{M}=5.75, \mathrm{SD}=0.71)$ than those collected during the wet season $(\mathrm{n}=$ $13, \mathrm{M}=5.38, \mathrm{SD}=0.57) ; \mathrm{z}=-1.818, \mathrm{p}=0.03$. 
The drop of $\mathrm{pH}$ values during the wet season might be contributed to run-offs that increase dilution and hence increase the concentrations of hydrogen ions that consequently reduce the $\mathrm{pH}$. This has also been found by other researchers, e.g., Girardi et al (2016) who studied water quality changes in rivers during rain events, and found that $\mathrm{pH}$ values showed some decreasing trends during rainfall. When the data on water temperature were subjected to similar comparison test, it was observed that wet season temperatures were significantly higher $(\mathrm{n}=13, \mathrm{M}=22.65, \mathrm{SD}=2.34)$ than the dry season temperatures $(\mathrm{n}=13, \mathrm{M}=20.72$, $\mathrm{SD}=1.76), \mathrm{z}=-2.692, \mathrm{p}=0.01$. This is to be expected since the month of June when the dry season sampling was conducted is colder than March when the wet season sampling was conducted, in the whole of the Southern Highlands area (Mbululo and Nyihirani 2012) despite the rainfall.

Statistically significant seasonal trends were also observed for both EC and TDS measurements. Higher EC values were recorded during the dry season $(\mathrm{n}=13, \mathrm{M}=$ $47.32, \mathrm{SD}=32.12)$ than the wet season $(\mathrm{n}=13$, $\mathrm{M}=44.06, \mathrm{SD}=28.00), \mathrm{z}=-1.433, \mathrm{p}=0.02$. Similarly, higher TDS values were observed during the dry season $(\mathrm{n}=13, \mathrm{M}=23.16, \mathrm{SD}=$ 15.49) than the wet season $(\mathrm{n}=13, \mathrm{M}=18.61$, $\mathrm{SD}=10.26), \mathrm{z}=-2.227, \mathrm{p}=0.02$. These variations might be attributed to the fact that during the dry season, water levels and flow rates tend to be lower, hence concentrating the dissolved solids in them, while in the wet season there is a dilution tendency. This is similar to the findings reported by HellarKihampa et al. (2013) who obtained higher EC and TDS concentrations during the dry season than the wet season in river water from Pangani Basin in Tanzania, and Awoyemi et al. (2014) who reported similar results in surface water from Majidun area of Ikorodu, Benue State in Nigeria.

Both TSS and turbidity data showed that the concentrations were significantly higher during the wet season than the dry season $(n=$ $13, \mathrm{p}<0.05$ ). Higher TSS levels during the wet season may be attributed to increased run-offs from the fields that carry many materials during the rainfalls. The same trend was also found by Anhwange et al. (2012) who studied seasonal variations of water quality parameters of river Benue, Makurdi Metropolis, Nigeria. Further to that, studies have shown that turbidity of natural waters tends to increase during runoff events as a result of increased overland flow and erosion (Girardi et al 2016). There was also a decrease in DO levels during the wet season $(n=13, M=13.12, S D=4.58)$ when compared to the dry season $(\mathrm{n}=13, \mathrm{M}=$ 18.57, $\mathrm{SD}=3.23), \mathrm{z}=-3.061, \mathrm{p}=0.02$. This can be attributed to the increased level of FC during the wet season since high levels of FC are associated with decreased DO levels (Rossi et al. 2006). In this study, the two parameters were found to be negatively correlated $(\mathrm{r}=$ 0.513 ) as shown in Table 4. When applied on the nutrients data, the statistical test showed a significant difference in $\mathrm{NO}_{2}^{-}-\mathrm{N}$ concentrations between the two seasons, with higher values recorded during the wet season $(p=0.02)$. This is probably due to the same reason of inflow of agricultural runoffs from the nearby farms during rainfall.

\section{Spatial variations of the measured parameters and their implications to land- use practices}

Cluster analysis by HCA using average linkage between groups, was employed to assess the similarities and differences between the 13 sampling sites as depicted in Figure 2 


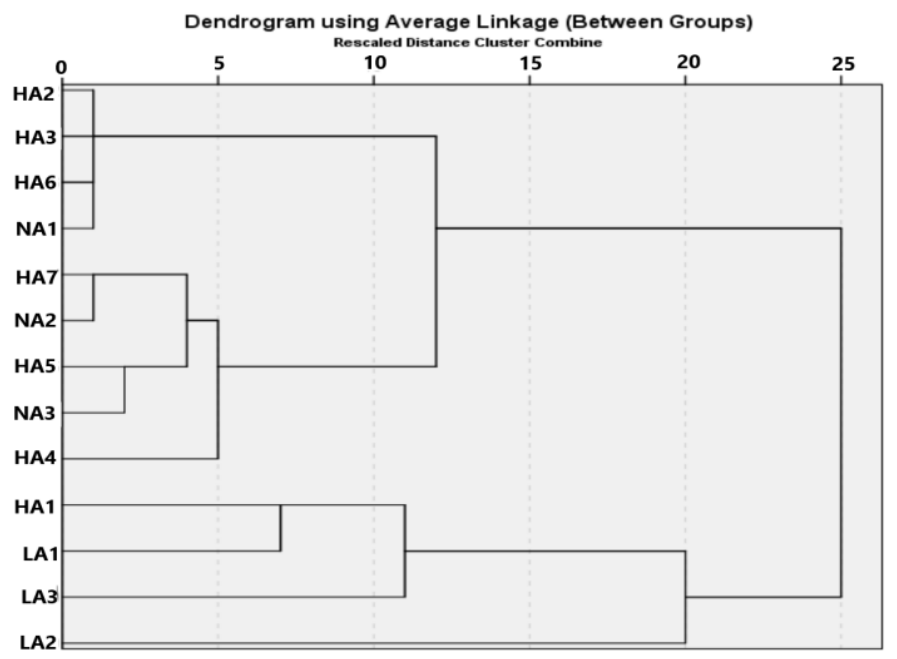

Figure 2: Dendrogram of the cluster analysis of the 13 investigated stations.

The HCA characterizes the sampling locations based on the measured parameters and groups them in various clusters following the observed patterns. The results in Figure 2 reveals an initial splitting of the tree to form two clusters; the top cluster (Cluster 1) that contains nine sites (HA2, HA3, HA6, NA1, HA7, NA2, HA5 NA3 and HA4) and the bottom cluster (Cluster 2) that contains four sites (HA1, LA1, LA3, LA2). Considering the previous grouping (Table 1), it can be observed that with the exception of HA1 which belongs to Cluster 2, all stations in the highland area (HA) and the newland area (NA) are grouped together in Cluster 1, while Cluster 2 contains stations that belong to the lowland area (LA). This shows that as previously predicted, the concentration patterns of the measured water quality parameters reflect the distinct characteristics of the locations.

Cluster 1 is further split into two groups, with HA2, HA3, HA6 and NA1 in one group and HA7, NA2, HA5, NA3 and HA4 in another group. The further splitting of Cluster 2 shows that the three LA stations are clearly different from HA1. From Figure 1 it can be observed that indeed the three LA stations are characterized by the highest concentrations of EC, TDs and TSS. Furthermore, LA2 also had the highest level of turbidity, while the lowest values were measured in samples from the three NA stations. It can thus be contended that, being at the most downstream location with more agriculture and livestock keeping activities compared to the other two locations, the lowland area was the most contaminated part.

\section{Conclusions and Recommendations}

Water samples from a catchment used for municipal supply system in Mbinga District, Songea Region, in the Southern highlands of Tanzania have been characterized for physicochemical parameters, faecal coliform and nutrients. The obtained results show that the water quality is generally within the national (TBS) and the WHO guidelines for drinking water standards, although there were few exceptions that exceeded limits for some parameters at a few locations. The observed seasonal variations of the measured parameters show a general decrease in water quality during the wet season in terms of decreased $\mathrm{pH}$ values, increased TSS, turbidity, $\mathrm{FC}$ and $\mathrm{NO}_{2}^{-}-\mathrm{N}$ concentrations and decreased DO levels. The grouping of the sampling stations by the HCA confirmed the previous prediction on the significance of land-use practices, where the 
three most downstream locations with the highest agriculture and livestock keeping activities had the least quality of water. It can therefore be concluded that land-use practices largely influenced the quality of water in the catchment. These results provide new insights into the environmental quality of the catchment. They also demonstrate that, even though most parameters were within the permissible limits of drinking water standards, there is a need to take appropriate measures of pollution control by the concerned authorities to keep the water quality within the permissible limits as the population and human activities in the area are increasing. Furthermore, since the study area is characterized by farming activities where the use of pesticide is common, a further study to assess pesticide residues and other chemical contaminants in water and other environmental segments in this area is important.

\section{Acknowledgements}

We are grateful for the support provided by the Ruvuma Regional Water Laboratory.

\section{Declaration of Interest}

Authors declare that there is no any competing or conflicting interest.

\section{References}

APHA/AWWA/WEF (American Public Health Association/American Water Works Association/, and the Water Environment Federation) 2005 Standard methods for the examination of water and wastewater. $21^{\text {st }}$ Edition. Alexandria, VA: WEF Publishing.

Anhwange BA, Agbaji EB and Gimba EC 2012 Impact assessment of human activities and seasonal variation on River Benue, Makurdi Metropolis. Int. J. Sci. Technol. 5: 248-254.

Araoye PA 2009 The seasonal variation of $\mathrm{pH}$ and dissolved oxygen (DO) concentration in Asa lake Ilorin, Nigeria. Int. J. Phys. Sci. 4(5): 271-274.

Awoyemi OM, Achudume AC and Okoya AA 2014 The physicochemical quality of groundwater in relation to surface water pollution in Majidun Area of Ikorodu, Lagos State, Nigeria. Am. J. Water Resour. 2(5): 126-133.

Baird R and Bridgewater L 2017 Standard Methods for the Examination of Water and Wastewater, 23 ${ }^{\text {rd }}$ Ed. Washington, DC.

EWURA (Energy and Water Utilities Regulatory Authority) 2020 Water and Wastewater Quality Monitoring Guidelines for Water Supply and Sanitation Authorities, $2^{\text {nd }}$ Edition, Dodoma, Tanzania.

EU (European Union) 2017 Drinking Water Amendment Regulations 2017, Statutory Instruments S.I. No. 464 of 2017.

Ferrer N, Folch A, Masó G, Sanchez S and Sanchez-Vila X 2020 What are the main factors influencing the presence of faecal bacteria pollution in groundwater systems in developing countries? J. Contam. Hydrol. 228: 103556.

Girardi R, Pinheiro A, Garbossa LHP and Torres É 2016 Water quality change of rivers during rainy events in a watershed with different land uses in Southern Brazil. Brazil. J. Water Resour. (21)3: 514-524.

Hellar-Kihampa H, De Wael K, Lugwisha E and Van Grieken R 2013 Water quality assessment in the Pangani River Basin, Tanzania: natural and anthropogenic influences on the concentrations of nutrients and inorganic ions. Int. J. River Basin Manage. 11(1): 55-75.

Kangalawe RYM and Lyimo JG 2010 Population dynamics, rural livelihoods and environmental degradation: Some experiences from Tanzania. Environ. Dev. Sustain. 12(6): 985-997.

Manuel J 2014 Nutrient pollution: a persistent threat to waterways. Environ. Health Perspect. 122(11): A304-A309.

Mataba GR, Verhaert V, Blust R and Bervoets L 2016 Distribution of trace elements in the aquatic ecosystem of the Thigithe River and the fish Labeo victorianus in Tanzania and possible risks for human consumption. Sci. Total Environ. 547: 48-59. 
MDC (Mbinga District Council) 2016 Status of the Mountains Ecosystem in Mbinga District (Unpublished).

Mbululo Y and Nyihirani F 2012 Climate characteristics over Southern Highlands Tanzania. Atmos. Clim. Sci. 02(04): 454463.

Mihale MJ 2015 Nitrogen and phosphorus dynamics in the waters of the Great Ruaha River, Tanzania. J. Water Resour. Ocean Sci. 4(5): 59-71.

Mishra A, Benham BL and Mostaghimi S 2008 Bacterial transport from agricultural lands fertilized with animal manure. Water Air Soil Pollut. 189: 127-134.

Myers DN and Sylvester FD 1997 National field manual for the collection of waterquality data-biological indicators. USGS Techniques of Water Resources Investigations.

National Bureau of Statistics (NBS) 20132012 Population and Housing Census: Population distribution by Administrative Areas, National Bureau of Statistics, Ministry of Finance, Dar es Salaam, Tanzania. Retrieved on July 29, 2021, from http://www.nbs.go.tz/

Nindi SJ 2004 Dynamics of land use systems and environmental management in the Matengo Highlands, Tanzania. PhD Thesis, Kyoto University, Japan.

Patil PN, Sawant DV and Deshmukh RN 2012 Physico-chemical parameters for testing of water-a review. Int. J. Environ. Sci. 3(3): 1194-1207.

Rahmanian N, Ali SH, Homayoonfard M, Ali NJ, Rehan M, Sadef Y and Nizami AS 2015 Analysis of physiochemical parameters to evaluate the drinking water quality in the State of Perak, Malaysia. $J$. Chem. 2015: 716125.

Rohrer J 2013 Re: Why is the concentration on nitrate always higher than that of nitrite in Solutions? Retrieved from:
https://www.researchgate.net/post/Why-isthe-Concentration-on-Nitrate-alwayshigher-than-that-of-NitriteinSolutions/52c1be22d4c11834638b4718/d

Rossi L, Fankhauser R and Chèvre N 2006 Water quality criteria for total suspended solids (TSS) in urban wet-weather discharges. Water Sci. Technol 54(6-7): 355-362.

Rowhani P, Lobell DB, Linderman $\mathrm{M}$ and Ramankutty N 2011 Climate variability and crop production in Tanzania. Agric. For. Meteorol. 151(4): 449-460.

Siosemarde M, Kave F, Pazira E, Sedghi H and Ghaderi SJ 2010 Determination of constant coefficients to relate total dissolved solids to electrical conductivity. World Acad. Sci. Eng. Technol. 46: 258-260.

Shagega FP, Munishi SE and Kongo VM 2020 Assessment of potential impacts of climate change on water resources in Ngerengere catchment, Tanzania. Phys. Chem. Earth, Parts A/B/C, 116: 102804.

TBS (Tanzania Bureau of Standards) 2008 (TZS 789:2008) Drinking (potable) Water: Specification. National Environmental Standards Compendium (NESC), Tanzania Bureau of Standards, Dar es Salaam, Tanzania, pp 26-27.

Tyrrel SF and Quinton JN 2003 Overland flow transport of pathogens from agricultural land receiving faecal wastes. J. Appl. Microbiol. 94: 87-93.

US EPA (US Environmental Protection Agency) 1994 Water-quality criteria, standards or recommended limits for selected properties and constituents. Washington, DC.

World Health Organization (WHO) 2011 Guidelines for Drinking Water Quality, $4^{\text {th }}$ Edition. WHO Library Cataloguing-inPublication, Switzerland. 